DOI https://doi.org/10.18551/rjoas.2018-12.39

\title{
COMMUNAL CONFLICT: ANALYSIS OF ERVING GOFFMAN'S DRAMATURGY THROUGH A CASE STUDY
}

\author{
Benjamin, Lecturer \\ Faculty of Social and Political Sciences, University of Lampung, Indonesia \\ E-mail: bensosunila@gmail.com
}

\begin{abstract}
This paper discusses the incident of communal conflict between people in Balinuraga and Agom Villages, Lampung Province from Goffman's Dramaturgy point of views. A case study and qualitative research method were used and data was collected through purposive sampling technique using: in-depth interview; observation; and documentation. Data was analyzed through qualitative approach with the process of data reduction, presentation, and conclusion. The location of research studies was in Agom and Balinuraga Villages, South Lampung Regency. This paper examines that the peak incidence of communal conflict between villagers resulting from lack of constructive handling conflict management in preventing and reducing conflict. This paper revealed that the incidence of conflict or intersection occurred due to lack of comprehensive handling efforts since there is the fact that the process of cessation of conflicts and acts of violence were perpetrated by military intervention. This paper, therefore, suggests that in dealing and handling conflict, it is necessary to absorb various aspirations of conflicting society, rather than top-down approach. In addition, indigenous institutions as a counterpart of local customs and forum for cultural preservation should have more roles in resolving conflicts so that the functioning of customary institutions is expected to safeguard, enhance, and preserve the culture of each party in conflict.
\end{abstract}

\section{KEY WORDS}

Communal conflict, Goffman's dramaturgy, ethnicity, culture.

Indonesian society is a pluralistic society in terms of religion, ethnicity, norms and culture. This pluralistic situation potentially leads to conflicts several mechanisms of the interactions of people in the community such as parking areas ownership and management, agricultural land disputes and miscommunication in the community due to different communication styles (Wirawan, 2010). In addition, the conflict is often triggered by the economic jealousy and by the government's policy response which is, in some extent, not in line with the aspirations of the community, the feeling of disappointment related to issues of ethnicity and religiosity (Burhanudin, 1998). According to Susan (2010), conflicts can occur horizontally among communities, as well as vertically between communities and government apparatus. As a result, new problems appear such as poverty, unemployment, social rivalry on economic resources, violence vengeance and sexual harassment (Wirawan, 2010; Sihbudi, 2001; Faturochman and Nuraeni, 2006; Umar, 2011). Social conflict in the local context of Lampung is often driven by religious differences, new administrative arrangement of village area, and youth violence. All these are categorized as horizontal conflict. A study by Wirawan (2010) stated that horizontal conflict is common in Indonesia and one of the trigger is the competition in the seizure of women. In addition, common causes such as dancing party in music venue, parking area ownership and sexual harassmen are real in the community.

Previous research, for example Umar (2011), examines social conflict in the District of Johar Baru, Central Jakarta Indonesia in relation to the existence of youth gangs and the high rate of unemployment. A study by Yara (2002) has shown a communal conflict between residents of Palmeriem region and residents of Berland Matraman area, Matraman subdistrict, in East Jakarta. In addition, Fanani (2001) examines conflict mitigation efforts conducted by Matraman Police. Fanani found that conflict management was ineffective and 
there is no a significant impact on the settlement of the conflict among residents of Matraman. Thus, based on previous studies on social conflicts, the causes of social conflict result from the dynamics of socio-economic change, economic competition and unemployment, violence and in-effective of institutions in dealing with conflicts.

Social conflict in the community often occurs in Indonesia, for example, in the case of Jayapura where the economic and political factors related to poverty, backwardness and alienation of life have been increasingly dominated by groups of immigrants such as Javanese and South Sulawesi. However, the case of Mataram occurred between indigenous people and Chinese descent driven by economic factors. Another case is the riots in Medan because of the tension between the followers of religion, motivated by the establishment of houses of worship, practice of religious ceremonies, and the broadcasting of religion (Burhanudin, 1999). In relation to the number of conflicts among people in the community, there were big incident of conflict in Lampung after 2008, namely: a. Conflict between villagers of Bali Agung Palas District with residents of Palas Pasemah village in December 2009; b. Conflict between Sidomakmur residents of Way Panji District with residents of Dusun Sukajaya Margocatur Village Kalianda in November 2011; c. Conflict between people of Napal Hamlet and the villagers of Kotadalam in January 2012; d. Conflicts between villagers Agom with Balinuraga villagers in South Lampung regency, in October 2012. Although those conflicts were in different locations, they are still in the same Regency. Military approach is still maintained in dealing with those conflicts, while cultural and mediation approaches as a form of communication for conflicting parties are often ignored (Hendrajaya, et al., 2010)

In dealing with conflicts in order to achieve better policy and defense strategy, there are several ways of strategy: a. maintaining peace in society; b. developing a peaceful dispute resolution system; c. tampers of potential conflict. Whereas in Law Number. 7 of 2012 on Handling of Social Conflict, in Part Four and Article 9 emphasizes, that the Central and Local Governments are obliged to reduce the potential for conflict in the community, by intensifying dialogue between groups of people. This is in line with Fisher's (2001) which states that dialogue is essential way for handling conflicts. Thus, this research was conducted through looking at some previous research gap and facts in the field of conflict resolution and ended up with finding several research gaps. They are: a) constructive conflict management is still weak in handling, preventing and reducing conflict, b) conflict incidents occurring in the area occurred due to lack of comprehensive handling efforts. Therefore, this research aims to understand: a) how to manage weak constructive conflict in handling, preventing and reducing conflict; b) what is the highest incidence of conflicts occurring in the location area due to lack of comprehensive handling efforts.

\section{METHODS OF RESEARCH}

This research was conducted using qualitative approach and case study. A case study is a thorough investigation of a program, event, activity, process or group of individuals (Creswell, 2014). Data was collected through purposive sampling technique with informants who understand and get involved in conflict and/or who have information related to conflict among people in the community. They are informal leaders from two conflicting villages, youth leaders, and representatives of conflicting parties who have structural positions in the community, such as Village Heads, or Village Devices (Carik or the Chief of Hamlet and Officers). Data was obtained from: a) in-depth interview, b) observation, c) documentation study. Data was processed and analyzed through the process of reduction and interpretations. Transcription and categorization of data were conducted through reduction and interpretation in relation to the research objectives. In connection with the process of qualitative data analysis, Miles and Huberman (1994) explain that data analysis can be done by data reduction (data sorting process), display (data presentation), verify (drawing conclusion). The location of this research is in the area of conflict between villagers in Agom village and Balinuraga Village in South Lampung Regency. 


\section{RESULTS AND DISCUSSION}

According to Fisher conflict stage, the biggest or the peak of incident of the conflict is known as the crisis phase, where violent tensions arise leading to large-scale of conflicts such as wars, wounded and killed from both conflicting sides. In addition, bad communication among conflicting parties leads to a high tension of conflict. In relation to a high tension of conflict, the attitude, behavior and situation of the conflict of the Balinuraga villagers, originally were tempted by two girls of Agom Village, when they got accident from motor cycle. They were helped by a group of young people, but they were rumored to be sexually abused and the young people did not want to be responsible from their actions. The negotiation and dialogue did not work resulting the first attack and riot. The behavior of parties involved in the conflict tends to strained relationship, emphasizing the selfishness of attackers and who were attacked in the conflict. For people who were participated in the conflict, they devoted their sense of empathy, contributed to temporary emotions and they had a sense of Sebatin as members of the community of South Lampung. Some people they were confused where they did not understand the situation and what they did was only to protect their village.

In the beginning of the Balinuraga conflict, a teenage girl parent visited Balinuraga village to call for responsibility of young people's families. However, villagers of Balinuraga have been ready with weaponry, such as air rifles and sharped weapons to protect and attack villagers of Agom. As a result, two people from Agom Village were injured and one motorcycle unit was burned. On Sunday evening of October 27 in 2012, the attackers were also carried out by a group of people from the village of Agom. They gathered at Pasar Patok Sidorejo and spread out to the settlements in Bali Balinuraga Village, Way Panji Subdistrict, and they destroyed and burned five houses. A stall of agricultural medicines and a grocery store were caught fire and seven houses were damaged by stones. The next day, some villagers of Agom with the help of surrounding villagers went back to Balinuraga village, where they killed 3 people using firearms and sharped weapons and seven people were injured and were hospitalized, based on the explanation of the government officers in Kalianda. Since there was only few of a casualty, Agom people finally retreated and returned to his village. For a while, the fighting and riot were stopped with consideration of the weakness of strategy. On Sunday night, messages through mobile phone were distributed through communication networks.

The messages are:

"Best regards to our people "Buay Raden Intan and Raden Imbo". Your families in Kalianda are attacked; we have no power and there are 9 people killed, so please help us immediately. Spread these messages to others. Thanks to Sai Bumi Ruwai Jurai. Lampung Unite".

Further, each village spread out the messages through mosques and people prepared weapons for assault Balinuraga villagers. The night situation was very gripping; the villagers of Agom were maintaining various types of weapons for attacking Balinuraga on the next day. One of villagers from Agom Village said:

"Various kinds of weapons were prepared for use as needed to find out Balinuraga people. We were carrying short and long swords, machetes, spears, fish bombs, Molotov bombs, and bamboo spears".

Furthermore, to know the existence of magic elements occurred in conflict, people brought salt, moringa and short swords. People also brought with them young coconut leaves (Janur), putting on their necks to keep them safe from magic. Janur or coconut leaves are a sense of immunity for people if they put them on their necks. The most commonly used for their weapons were bamboo spikes. People believe that magic can be stopped if people use natural weapons such us from bamboo when they are fighting". In relation to preparation for the attack from the Agom villagers' side, there were various weapons to know weaknesses of Balinuraga Village residents, such as using salt, Kelor leaf and short swords (Keris). The tools and materials used on the weapons can only be encountered during conflict and believe in existence the power of the magic element. Similarly, using those 
weapons, people from Agom Villagers can break the immaterial or supernatural of village border in the Balinuraga village which has been unknowingly installed by the leader of the tribe, so that the outsiders (Agom villagers) can pass through and enter Balinuraga Village safely, as expressed by an informant below:

"We use a variety of weapons to find out Balinuraga residents. Based on the tools used can see the element of magic that occurs during conflicts. We brought salt, Kelor leaves and Keris".

People from outside Lampung were given Janur on their necks for safety reason from magic attack. The use of leaf was for the sake of a meaningful safety as an antidote to the power of magic containing a sense of immunity for the wearers of Janur. Next as a sign / symbol indicating the user is a group of Agom villagers who must be protected during the conflict.

Conflict between Balinuraga residents involved residents from various areas inside and outside South Lampung regency. They were equipped with various weapons to fight and infiltrate Balinuraga Village. On Monday morning around 10.00 am local residents from several villages around Agom Village and even from outside South Lampung District visited Agom Village, Kalianda District, South Lampung using motor cycles and cars and they gathered in Agom Village field before attacking Balinuraga Village. Considering their strategy of previous attacks, at the peak of the attack on Monday, 29 October 2012, Agom residents about 20,000 people in total at 08.00 am gathered to attack the Balinuraga villagers. One of informant said:

"People from various elements helped the residents of Lampung Agom in conflict. The dynamics of conflict movement among people was because not only people of Lampung Agom who have unresolved problems with Balinuraga residents, but also many other citizens in this South Lampung who also had been a victim of the act of Balinuraga people. With the movement begun by the residents of Lampung Agom, many of the other residents who participated blended in their vengeful feelings. But it is unfortunate when the citizens who participated in the conflict actually had other intentions, such as loot valuable goods and also damaged existing public facilities; there were possibility of people to benefit their selves".

Violence as discussed by Englander (2009) means the hostile aggression assault and aggression of violence mobilized to injure, to torture or annihilate opponents. The tendency of hostile aggression occurs when conflicting groups have entered the phase of mutual revenge. Unlike the case of Balinuraga residents, the Agom villagers and supporters were driven by Sebatin as citizens of the community of South Lampung. Moreover, people from Agom village gathered in front of the Kalianda Mosque, Jati Indah at the intersection of Lubuk Village and the crossing of Agom Village on Provincial Motor Way of Sumatra were blockaded by the police using police trucks along with hundreds police personnel. However, people could enter the blockade about 20 thousands people carrying various weapons ranging from swords, Keris, spears, machetes, fish bombs, Molotov bombs, bamboo weapons at $10.00 \mathrm{pm}$. After arriving in the battle field and waiting for attack, thousands of people simultaneously said religious world "Allah Akbar".

"Chronologically, around 12:15 pm after praying, Agom villagers and people outside the village moved to Balinuraga Village with a distance of about $10 \mathrm{~km}$. Their vehicles were parked at Patok Market of Way Panji Subdistrict, and continued walking across Sidorejo Village and Sidoreno Village, Way Panji District. They arrived at the border of Sidoreno Village with Balinuraga Village around $13.30 \mathrm{pm}$, as described by Sidoreno Village Youth Leader, that "Saturday night began an attack on Balinuraga Village, in the morning and again in the afternoon the attack was carried out. Monday afternoon there was a massive assault taking place. Conflicts between villagers of Agom and Balinuraga villages caused Sidoreno Village only as victims. Because in our village there are also Balinese people although Sidoreno Village was not involved in the problem".

Arriving at the gate of Balinuraga, they were confronted by a police blockade using a barracuda car with teargas fires. Thousands of police, Marines, and Army could not stop the massive and violent mass. Barbed wire as a barrier and car apparatus was overturned due to their ferocity. Police just stayed in the place to see the mobs already besieging the village of 
Balinuraga from three different corners of the village. At around $4 \mathrm{pm}$, finally the mass went back home while returning to recite Takbir "Allahu Akbar" constantly. In no less than two hours, situation at Balinuraga Village was ravaged where Balinuraga houses were burned with black smoke soaring to the sky. See table 1 for details of chronology of Balinuraga conflict from 27 to 29 October 2012.

It seems that the conflict can be described on how great their sense of empathy, a sense of togetherness and sense Sebatin as fellow citizens of the South Lampung community. The conflict is an outburst of angry emotion for the people of Agom village against Balinuraga villagers resulting the piling up of the resentment of South Lampung residents to the attitude and behavior of Balinuraga villagers and residents of Bali in South Lampung. Based on data, it can be described that there are of conflict clashes on the first attack, second attack, and to the crisis stage, which is similar to the symbolic theory of dramaturgy from Goffman. When heading to Balinuraga Village, it is like a front stage, where it is accompanied by a personal front with verbal language and body language from the attackers of Agom villagers and their mass supporters through reciting Islamic words "Allahu Akbar".

Table 1 - Chronological Details of Conflict

\begin{tabular}{|c|c|c|c|}
\hline No & Date & Time & $\begin{array}{ll} & \text { Description } \\
\end{array}$ \\
\hline 1. & $\begin{array}{l}\text { Saturday, } 27 \\
\text { Ocotober } \\
2012\end{array}$ & $17.30-18.00$ & $\begin{array}{l}\text { Two teenage girls from Agom Village returned from the Patok Village Sidoharjo } \\
\text { Market, were tempted by Balinuraga Village youths to fall from the motorbike. } \\
\text { Victims were helped; there was a gossip of sexual harassment. Victims were taken } \\
\text { home by residents to their parents and at night they were brought to the hospital. }\end{array}$ \\
\hline 2. & $\begin{array}{l}\text { Saturday, } 27 \\
\text { October } 2012\end{array}$ & At night & $\begin{array}{l}\text { A group of residents and the head of Agom village represented the victim's parents } \\
\text { visiting KAD Balinuraga to ask for accountability for the incident. However, there was } \\
\text { no failure in the compensation agreement in the non-communicative dialogue; then } \\
\text { they were reported to the police and customary leaders of South Lampung. }\end{array}$ \\
\hline 3. & $\begin{array}{l}\text { Saturday } 27 \\
\text { October } 2012\end{array}$ & At night & $\begin{array}{c}\text { People searched the abusers but they received resistance from hundreds of } \\
\text { Balinuraga Villagers who were ready to fight with complete weapons to block and } \\
\text { attack the villagers of Agom. As a result, two villagers of Agom were injured and a } \\
\text { motorcycle was burned. }\end{array}$ \\
\hline 4. & $\begin{array}{l}\text { Saturday } 27 \\
\text { October } 2012\end{array}$ & $\begin{array}{l}\text { At night (small } \\
\text { attack) }\end{array}$ & $\begin{array}{l}\text { A group of Agom villagers gathered at the Patok Sidorejo Market and attacked the } \\
\text { Balinese settlements on the border of Balinuraga Village, and destroyed } 5 \text { houses. }\end{array}$ \\
\hline 5. & $\begin{array}{l}\text { Saturday } 27 \\
\text { October } 2012\end{array}$ & At 22.30 & $\begin{array}{l}\text { People from the Way Panji District were assisted by around } 1 \text { group of Police } \\
\text { Officers from Sidomulyo police and South Lampung District Police tried to prevent it. }\end{array}$ \\
\hline 6. & $\begin{array}{l}28 \text { October } \\
2012\end{array}$ & $\begin{array}{l}\text { Sunday morning } \\
\text { (small attack) }\end{array}$ & $\begin{array}{l}\text { Other villagers from Agom Village came to Balinuraga Village so that clash broke out } \\
\text { and resulted three residents of Agom Village being knocked down by rifle bullets. }\end{array}$ \\
\hline 7. & $\begin{array}{l}28 \text { October } \\
2012\end{array}$ & $\begin{array}{l}\text { Sunday } \\
\text { afternoon at } \\
13.00 \text { (Second } \\
\text { attack) }\end{array}$ & $\begin{array}{l}\text { Attack on Balinuraga villagers, they were greeted with short-barreled firearms, } \\
\text { resulting one person being shot dead on the head and two people affected by } \\
\text { gunshot wounds in the legs. }\end{array}$ \\
\hline 8. & $\begin{array}{l}28 \text { October } \\
2012\end{array}$ & Sunday night & $\begin{array}{l}\text { Distribution of messages via mobile phone to send information that Balinuraga } \\
\text { Villagers have killed Lampung Agom people. }\end{array}$ \\
\hline 9. & $\begin{array}{l}28 \text { October } \\
2012\end{array}$ & Sunday night & $\begin{array}{l}\text { Preparing of weapons to attack such as swords, Keris, machetes, spears (iron bars } \\
\text { and pointed bamboo), bombs (fish/ molotov and igniter / matches), knives, salt and } \\
\text { Moringa leaves. The most widely used weapon is pointed bamboo, which has } \\
\text { purpose to be immune to the power of magic. }\end{array}$ \\
\hline 10. & $\begin{array}{l}\text { Monday } 29 \\
\text { October } 2012\end{array}$ & $09.00 \mathrm{am}$ & $\begin{array}{l}\text { Residents of Lampung, Agom Village, who received supports with a mass power of } \\
\text { around } 20,000 \text { people from various regions in Lampung. They gathered at the Agom } \\
\text { Village soccer field. }\end{array}$ \\
\hline 11. & $\begin{array}{c}\text { Monday } 29 \\
\text { October } 2012\end{array}$ & $08.00 \mathrm{am}$ & $\begin{array}{l}\text { At the intersection of Lubuk Village and Agom Village the Sumatra Cross Road was } \\
\text { blocked by the police using trucks along with hundreds of police personnel. }\end{array}$ \\
\hline 12. & $\begin{array}{l}\text { Monday } 29 \\
\text { October } 2012\end{array}$ & $\begin{array}{l}14.00-16.30 \\
\text { The Peak of } \\
\text { Conflict }\end{array}$ & $\begin{array}{c}\text { Plans for an attack were carried out at 10:00 a.m., but at the consideration of the } \\
\text { Customary Leaders of the Raden Imba and Lima Marga, South Lampung, the attack } \\
\text { was carried out during the day when the attacker was not finished. The attacker had } \\
\text { to leave Balinuraga Village. }\end{array}$ \\
\hline
\end{tabular}

In the conflict area, people constantly recited Allahu Akbar, going and back in attacking, speaking rude when meeting enemies, fierce facial expressions and emotionally and blindly attacks accompanied by attributes of everyday simple clothes, while setting personal fronts by carrying sharp weapons that have been be prepared. Referring to Goffman, attackers are like a show, but the impression of perpetrators of the show may vary. They act to attack something that is shown, which is different from everyday behavior. Furthermore, using Triangle of Conflict analysis from Galtung, there are several aggressive 
attitudes such as a perception about the attitude of Balinuraga villagers who seduced the girls of Agom village falling from motorcycles, be sexually rumored, and the process of dialogue was deadlock and perpetrators of sacrifices were hidden. Moreover, the situation was getting dangerous, where there was aggressive attitude through spreading news and the perception triggered by short messages (SMS), saying that Balinuraga villagers have killed the villagers of Agom. These caused massive mass movements to come from various regions inside and outside South Lampung area as a form of aggression behave $(P)$ in attacking Balinuraga villagers.

Attitudinal behavior put forward individual selfishness in the attack, while the opponents of Balinuraga villagers behaved in order to survive in the attack. Aggressive attitude (S) and accompanied by behavior aggression $(P)$ as the first and second attack behavior by Agom villagers who lost in strategy. The escalation of conflicts was increasing, with aggression behavior at the peak of the conflict $(P)$ formed by perceptions of the Agom villagers and their mass supporters (participation in conflict with empathy, instant emotion and mutual ownership of fellow South Lampung community members) Balinuraga villagers are manifested into a real action. A situation of contradictions $(K)$ the emergence of situations of conflict between Balinuraga residents involving attitude $(S)$ and behavior $(P)$ elements along with the elements of perception and concrete actions of each party living in the area of South Lampung Regency. Moreover, behind the stage (back stage), there was a direction or as an attack tactics or conflict tactics based on the recommendation of the Customary Characters of the White Blood Unity led by Raden Imba and Lima Marga of South Lampung, that the attack time was conducted at 23 to $4.30 \mathrm{pm}$. Here, the authors place the Dramaturgy Erving Goffman analysis centered on the attitude $(\mathrm{S})$ and behavior $(\mathrm{P})$ of the Triangle conflict theory of Galtung.

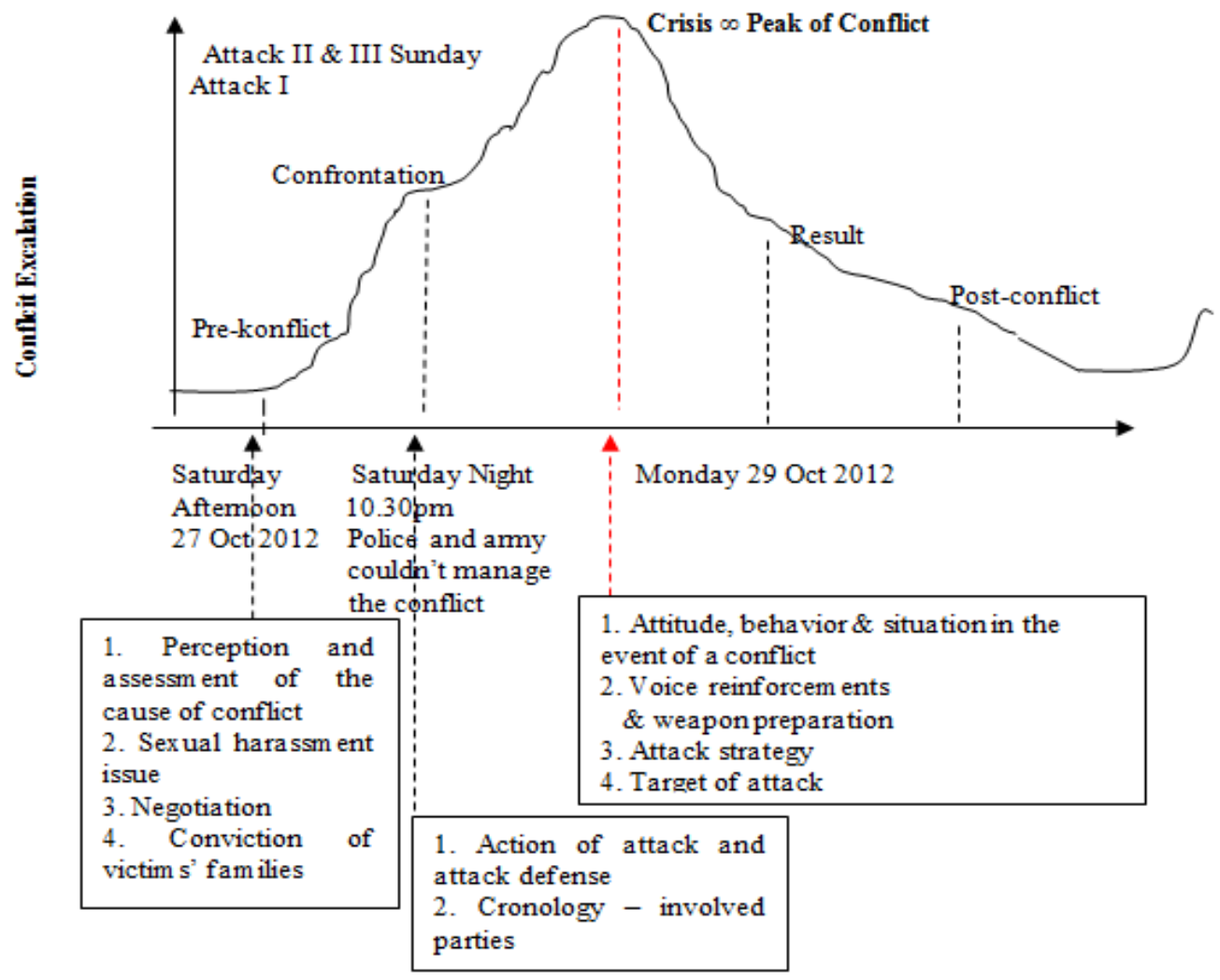

Figure 1 - Balinuraga Conflict

Apparently, what the Agom villagers did and the supporters attacked with violence, are in tune with Suseno (2000) in the introduction of the book Against Violence without Violence, where the culture of violence is a reality in the life of the Indonesian nation. Similarly, in this 
conflict there was a mass killing or fights between the Balinuraga villagers with the villagers of Agom. The mass support in the assault is also in line with the opinion of Selo Soemardjan (1999), stating that riots referr to collective action are spontaneous, disorganized and usually accompanied by acts of violence, either to destroy, loot goods, or attacking others as opposed to them. In the Balinuraga conflict, there were also the destruction and burning of schools, pretending to be a public facility. This is in accordance with the opinion of Galtung (1969), in which conflicts are accompanied by direct violence, destructions, such as physical infrastructure, schools and the act of killing or injuring the victims.

As for emerging other motives besides burning, destroying houses, looting is the act of certain parties who are not responsible and do not understand the root of conflict which is detrimental to the people of Agom village which can be impressed unfavorable from the perspective of outsiders who did not know the problem of conflict. Balinuraga villagers did not have time to run away and have a store to hand over their valuable possessions as ransom in order not to be killed. Apparently, there were certain parties as supporters to take advantage of the incident of the conflict as a chance to plunder valuable property belonging to Balinuraga Village residents. It is recognized by a person of the Agom village that attacking the villagers Balinuraga has a lot of is not because there are other motives. His main intention was to combat the idols in Balinuraga Village. There are outside parties who were plundering out of power and control, because supporters attacked aggressively. So in fact the main intention in Balinuraga attack is just to give lessons for Balinuraga Village people, while other motives are power and capability. In the Balinuraga conflict, this paper looked at the chronology of the conflict, where inter-ethnic conflicts indicate the escalation of conflict to the height of the conflict. However, there is no explicit clarity of the time of interval or phase of the conflict from one stage to another stage to the height of the conflict. Therefore, this paper aims to clarify by describing the chronology of the Fisher conflict to analyze the incidence of conflict among villagers in rural areas of agricultural areas of South Lampung Regency described as continuing in the form of linear curves whereas in the chronology of the conflicts of Fisher described these stages, it may be repeated in the same cycle in the form of a spiral, see Figure 1.

\section{CONCLUSION}

The peak incidence of conflict between villagers of Agom and Balinuraga of Sout Lampung Regency occurred due to several reasons: a) there is still weak of constructive handling management on conflict; b) there is lack of comprehensive handling efforts in the day of conflict. The fact is that the process of cessation of conflicts and acts of violence are still perpetrated by military intervention. Some suggestions for the development and study of communal conflict are as follows: 1) local governments in dealing with conflicts should be thoroughly resolved by absorbing the various aspirations of conflicting communities, rather than being top-down approach; 2) customary institutions as a counterpart of local customs and forum for cultural preservation should have more role in resolving conflicts. Functioning of customary institutions is expected to be safeguard, to enhance and preserve the culture of each party in conflict.

\section{REFERENCES}

1. Burhanudin, J. \& Subhan, A. (Ed). 1999. Sistim Siaga Dini Untuk Kerusuhan Sosial, Jakarta: Litbang Depag dan PPIM.

2. Creswell J.W. (2014).Research Design: Qualitativ, Quantitative and Mixed Methods Approaches. Thrid Edition. Los Angeles: SAGE Publication

3. Fanani, Y. (2001) Penanggulangan konflik tawuran warga Matraman. Unpublished Thesis, Universitas Indonesia. Retrieved from <http://lib.ui.ac.id/opac/ui/> on January $12^{\text {th }}, 2015$. 
4. Faturochman \& Nuraeni. (2006) Faktor Prasangka Sosial Dan Identitas Sosial Dalam Perilaku Agresi Pada Konflik Warga (Kasus Konflik Warga Bearland dan Warga Palmeriam Matraman Jakarta Timur), Sosiosains. XIX(1)

5. Fisher, S. (2001). Mengelola Konflik: Ketrampilan \& Strategi untuk Bertindak. Jakarta: The British Council, Indonesia.

6. Hartoyo. 2012. Memutus Mata Rantai Konflik di Bumi Lampung. In B. Budiman, Merajut Jurnalisme Damai di Lampung (Knitting Peace Journalism in Lampung). Lampung: Penerbit Aliansi Jurnalis lindependen (AJI) Bandar Lampung \& Indepth Publishing.

7. Hendrajaya, L., Fedyan, A., Kaban, P., Agusyanto, R., \& Etty, S. 2010. Ragam Konflik di Indonesia: Corak Dasar dan Resolusinya. Jakarta: Kementrian Pertahanan RI.

8. Jamil, M.M. (2007). Mengelola Konflik Membangun Damai: Teori, Strategi dan Implementasi Resolusi Konflik. Semarang: Walisongo Mediation Centre.

9. Miles, M.B. \& Huberman, A.M. (1994). Qualitative data analysis: A sourcebook of new methods. CA: Sage Publication

10. Nasikun. (1984). Sistem Sosial Indonesia. Jakarta: Rajawali Press.

11. Nulhaqim, S.A. (2007). Manajemen Kolaborasi Resolusi Konflik Dalam Perkelahian Antar Warga Di Daerah Perkotaan (Studi Kasus: Palmeriam dan Berland di Jakarta Timur). Retrieved from <http://soninulhaqim.blogspot.com/2007/12/manajemen-kolaborasiresolusi.html> on September, $12^{\text {th }}, 2013$.

12. Nuraeni \& Faturochman. 2006. Faktor Prasangka Sosial Dan Identitas Sosial Dalam Perilaku Agresi Pada Konflik Warga (Kasus Konflik Warga Bearland dan Warga Palmeriam Matraman Jakarta Timur). Jurnal Sosiosains, XIX(1). Retrieved from <https://www.acrobat.com/en_us.html > on June 13 ${ }^{\text {th }}, 2012$.

13. Spencer, D. \& Brogan, M. (2006). Mediation Law and Practice, Cambridge: Cambridge University Press.

14. Susan, N. (2010). Sosiologi Konflik dan Isu-Isu Konflik Kontemporer. Jakarta: Kancana Media Group.

15. Tohari, A., Saputra, D.Y., Yanuardi, D., Muntaza, D.N., Swanuri, L.T., \& Soumahu, R. (2011). Dinamika Konflik dan Kekerasan di Indonesia. Jakarta: Institut Titian Perdamaian

16. Umar, M. \& Anom, E. 2011. "TAWURAN" di Johar Baru Jakarta Pusat. Unpublished Research Report. Retrieved from <http://musniumar.wordpress.com/ 2011/10/08/laporanhasil-penelitian-tawuran-di-johar-baru/> on June 2017.

17. Wirawan. (2010). Konflik Dan Manajemen Konflik. Jakarta: Salemba Humanika

18. Yara, I.H.M.. 2002. Konflik komunal di Jakarta: Studi kasus di kawasan Matraman, Kecamatan Matraman, Jakarta Timur. Unpublished Thesis, Universitas Indonesia. Retrieved from <http://lib.ui.ac.id/opac/ui/> on January $12^{\text {th }}, 2015$

19. Yulianto. (2011). Membali di Lampung (Studi Kasus Identitas Kebalian di Desa Balinuraga Lampung Selatan). Jakarta: Widya Sari Press. 